\title{
МОТИВАЦІЯ ФОРМУВАННЯ ЗДОРОВОГО СПОСОБУ ЖИТТЯ СЕРЕД РІЗНИХ КАТЕГОРІЙ НАСЕЛЕННЯ
}

\author{
I. М. Мельничук, М. I. Сапіжак \\ ДВНЗ «Тернопільський державний медичний університет імені І. Я. Горбачевського \\ МОЗ Украӥни"
}

\begin{abstract}
У статті узагальнено, що стан здоров'я людини залежить не тільки від біологічних факторів, навколишнього та соціального середовища, а й від ціннісного ставлення людини до власного здоров'я. Мотивацію формування здорового способу життя серед різних категорій населення оцінено за результатами дослідження «Ставлення молоді України до здорового способу життя».
\end{abstract}

\section{MOTIVATION OF HEALTHY LIFESTYLE FORMING AMONG DIFFERENT POPPULATION CATEGORIES}

\author{
I. M. Melnychuk, M. I. Sapizhak
}

SHEI «Ternopil State Medical University by I. Ya. Horbachevsky of MPH of Ukraine»

The article summarizes that human health depends not only on biological factors, social environmental, but also on the value of human's attitude to health. Motivation of healthy lifestyle forming among different population categories is estimated at the conclusion of research «Attitude of youth in Ukraine to a healthy lifestyle».

Вступ. Протягом останніх десятиріч в Україні фіксується істотне погіршення стану здоров'я населення, що відображається у зростанні рівня захворюваності, смертності та скороченні тривапості життя. Не сприяє збереженню здоров'я молоді й високий рівень вживання спиртних напоїв, тютюнокуріння, вживання наркотичних речовин, проблема здорового харчування. Сповідування ідеології здорового способу життя передбачає зміну ставлення індивідуума та суспільства до стану особистого (а також і суспільного) здоров'я. Стан здоров'я людини залежить не тільки від біологічних факторів [1], навколишнього та соціального середовища, ай від того, чи становить власне здоров' я людини для неї цінність [3]. Саме це визначає, якою мірою людина готова дотримуватися здорового способу життя $[2,4]$, значною мірою, обізнаності щодо чинників, які визначають стан здоров'я [5].

(C) I. M. Мельничук, M.І. Сапіжак, 2014
Основна частина. Мотивацію формування здорового способу життя серед різних категорій населення нами оцінено за результатами дослідження «Ставлення молоді України до здорового способу життя", проведеного Державним інститутом розвитку сім'ї та молоді за підтримки ЮНІСЕФ, 2010 р. Отримані результати свідчать: $40 \%$ респондентів вважають здоров'я найважливішим у своєму житті; п'ята частина респондентів за найважливіше вважає матеріальний добробут; кожен дев' ятий - створення сім'ї.

Здоров'я як життєва цінність домінує в усіх вікових групах молоді, причому зі збільшенням віку його важливість для респондента лише зростає. Так, якщо у $14-17$ років його обрали $38,9 \%$, 18-24 роки - 36, 4 \%.

Здоров'я складає відносно більшу цінність для жінок, аніж для чоловіків (42,8\% проти 39,6\%), для мешканців районних центрів $(45,6 \%)$, сільської місцевості $(40,1 \%)$, аніж мешканців обласних центрів (35\%). 
Отже, попри певну ймовірну декларативність отриманих відповідей, сучасна українська молодь незалежно від віку, статі та місця проживання вважає здоров' я важливою цінністю свого життя.

На думку української молоді, стан здоров'я значною мірою залежить від таких загальних факторів, як шкідливі звички: токсикоманія $(91,4 \%)$, вживання наркотиків $(91,1 \%)$, вживання алкоголю $(87,8 \%)$, куріння $(85,7 \%)$; екологічна ситуація $(80,3 \%)$; особистого ставлення до свого здоров'я $(75,7 \%)$; правильного харчування $(73,6 \%)$; умов на роботі та вдома: умов праці (68\%), психологічної атмосфери вдома $(67,7 \%)$; наявності хронічних захворювань (62,7\%); матеріального благополуччя $(59,3 \%)$; заняття фізкультурою та спортом $(62,2 \%)$; режиму дня $(51,5 \%)$.

Проте на запитання, які чинники негативно впливають на їх власне здоров'я, більшість респондентів віддали перевагу стану навколишнього середовища $(66,4 \%)$. Це можнапояснити недостатньою поінформованістю про інші необхідні складові здоров'я, регулярним публічним обговоренням наслідків Чорнобильської аварії та інших екологічних негараздів.

Водночас такі відповіді можуть свідчити про прагнення молодих людей перенести власну відповідальність за підтримання власного здоров'я на зовнішні чинники, які мало залежать від конкретної людини. До найпоширеніших також належать психологічне напруження $(31,4 \%)$ та шкідливі звички $(30,4 \%)$.

Відповідаючи на питання «Що, на Вашу думку, негативно впливає на стан Вашого здоров' я?" (респонденти могли обрати не більше трьох варіантів відповідей), опитані визначили як найшкідливіший для себе чинник:

- у чоловіків: стан навколишнього середовища $(64 \%)$, шкідливі звички $(37,6 \%)$, психологічне напруження - 27,9\%;

- у жінок: стан навколишнього середовища $(69,1 \%)$, психологічне напруження (35\%), неправильне харчування (30,9\%);

- підлітки 14-17 років найчастіше обирали: стан навколишнього середовища (69\%), шкідливі звички $(32,8 \%)$, психологічне напруження $(24,5 \%)$;

- молодь віком 18-24 роки: стан навколишнього середовища (64,8\%), психологічне напруження $(31,4 \%)$, неправильне харчування $(31,2 \%)$ (саме в цій віковій групі поширені шкідливі звички, що згубно впливають на здоров'я).
Отримані дані свідчать про амбівалентність (неузгодженість, суперечливість у ставленні; прийняття двох взаємовиключних тверджень, конфлікт яких або не помічається, або ж свідомо чи несвідомо ігнорується) уявлень молоді щодо чинників здоров'я: у цілому вони слушно вважають, що головну роль відіграють як шкідливі звички, так і екологічна ситуація, умовипраці та відпочинку, але разом із тим, заявляють, що наїх здоров'я, основний вплив має стан навколишнього середовища. Для підтримання здорового способу життя молодь пропонує проводити більше часу на природі, активно відпочивати. Рівень та стиль життя, його соціальна якість виявились другорядними відносно навколишнього середовища, що може свідчити про недостатнє розуміння молоддю основ підтримання здоров'я.

Хоча значна частина молоді вважає здоров'я цінністю, проте піклуватися про нього вона не зовсім готова. Так, на запитання щодо міри піклування про власне здоров'я більше половини респондентів $(57,8 \%)$ обрали стриману відповідь «посередньо піклуюся». Лише третина $(32,2 \%)$ опитаних були більш впевнені стосовно власних дій та відповіли «добре піклуюся». Проте була й частка таких, що оцінили увагу до власного здоров'я дуже критично: 8,4 \% зупинилися на варіанті «погано піклуюся».

Варто зазначити, що із віком піклування про власне здоров'я слабшає. Так, у 14-17 років кількість тих, хто дбає про власне здоров'я «посередньо " та тих, хто дбає про власне здоров'я «добре» $\epsilon$ приблизно рівною - 48,7\% та 44,4 \% відповідно. Проте уже в групі 18-24 роки респондентів, які піклуються про здоров'я «посередньо», помітно збільшується $-57,4 \%$, тоді як тих, хто дбає про свій стан на рівні «добре», зменшується - 33,3\%. І вже зовсім очевидний дисбаланс у віковій категорії 25-35 років. Частка опитаних, що визначили своє ставлення до здоров'я як «посереднє» домінує $-61,2 \%$. Тих же, хто «добре» піклується про власне здоров'я, виявляється навіть менше половини від попередніх - 27,1%. Такі вікові відмінності можна вважати застережливими, адже серед 25-35-річних чимало людей сімейних і таких, що мають дітей, для яких вони слугують взірцем поведінки, прищеплюючи ї певні навички та цінності життя.

Отримані результати демонструють досить високий рівень активності української молоді. Так, 
лише біля $17 \%$ опитаних вважає, що життя залежить більше від них, аніж від зовнішніх обставин, $22 \%$ - більше покладаються на себе, аніж на зовнішні обставини, третина схиляється до думки, що їхнє життя однаково залежить і від них самих, і від зовнішніх обставин - $39 \%$, пасивність демонструє п'ята частина опитаних. При цьому суттєвих вікових відмінностей у відповіді на питання «Як Ви вважаєте, від чого головним чином залежить Ваше життя?" помічено не було, це стосується відмінностей між чоловіками та жінками або мешканцями різних типів населених пунктів.

Молодь називає здоров'я своєю цінністю, проте тільки третина молоді вважає, що вона добре піклується про своє здоров'я і до найефективніших заходів для підтримання здорового способу життя відносить активний відпочинок на природі, оптимальний режим праці та відпочинку та відмову від вживання міцного алкоголю. Молодь порізному реагує на проблеми зі здоров'ям і ставиться до їх вирішення, тобто рівень усвідомлення цінності здоров'я, відповідальності за його збереження та ступінь життєзбережувальної активності істотно відрізняються.

Методологічною основою формування позитивної мотивації на здоровий спосіб життя у молоді є гуманістичний підхід, сутність якого полягає у створенні сприятливої ситуації для їх готовності до сприйняття й адекватного реагування на виховні дії соціального середовища.

Рівень цієї готовності характеризується здатністю молоді перетворювати зовнішні вимоги на внутрішню мотивацію, поведінку з пробудженням їх самосвідомості і відповідальності за власну культуру.

Поняття «здоровий спосіб життя» розглядається у співвідношеннях тріади: здоров'я - здоровий спосіб життя - культура здоров'я.

Результатом сформованості здорового способу життя $є$ культура здоров'я як інтегративна якість особистості та показник вихованості, що забезпечує певний рівень знань, умінь і навичок формування, відтворення та зміцнення здоров'я і характеризується високим рівнем культури поведінки стосовно власного здоров'я та здоров'я оточуючих. Методологічним підґрунтям $\epsilon$ діяльнісний і системний підходи до формування здорового способу життя.

Критеріями формування позитивної мотивації на здоровий спосіб життя у молоді можна вважати:
- на рівні фізичного здоров'я: прагнення до фізичної досконалості, ставлення до власного здоров'я як до найвищої соціальної цінності, фізична розвиненість, загальна фізична працездатність, загартованість організму, дотримання раціонального режиму дня, виконання вимог особистої гігієни, правильне харчування;

- на рівні психічного здоров'я (психологічного комфорту): відповідність пізнавальної діяльності календарному віку, розвиненість довільних психічних процесів, наявність саморегуляціі, адекватна самооцінка, відсутність акцентуацій характеру та шкідливих поведінкових звичок;

- на рівні духовного здоров'я: узгодженість загальнолюдських та національних моральнодуховних цінностей, наявність позитивного ідеалу, працелюбність, відчуття прекрасного у житті, в природі, у мистецтві;

- на рівні соціального здоров' я (соціального благополуччя): сформована громадянська відповідальність за наслідки нездорового способу життя, позитивно спрямована комунікативність, доброзичливість у ставленні до людини, здатність до самоактуалізації, саморегуляції, самовиховання.

Формування здорового способу життя, культури здоров' я, підвищення їх виховних можливостей потребує максимальної ваги до мотиваційної сфери молоді у прагненні бути здоровими.

Мотивація до здорового способу життя - це система ціннісних орієнтацій, внутрішніх спонукань до збереження, відновлення і зміцнення здоров'я.

Серед форм і методів процесу формування здорового способу життя пріоритетна роль належить активним методам, що ґрунтуються на демократичному стилі взаємодіі, спрямовані на самостійний пошук істини і сприяють формуванню критичного мислення, ініціативи й творчості. До них також належать соціальне проектування, метод відкритої трибуни, ситуаційно-рольовагра, соціально-психологічний тренінг, інтелектуальний аукціон, "мозкова атака», метод аналізу соціальних ситуацій з морально-етичним характером, гра-драматизація тощо.

Доцільно застосовувати такі традиційні методи, як: бесіда, диспут, лекція, семінар, роз'яснення, переконання, позитивний і негативний приклади, методи вироблення звичок, методи вправ, контролю і самоконтролю, створення громадської думки тощо. 
Застосування цих методів сприяє розвитку в молоді адекватної моральної самооцінки, дає можливість організувати дієву роботу з формування позитивної мотивації на здоровий спосіб життя, знецінити і зруйнувати негативні мотиви, перебудувати і змінити негативні форми у поведінці дітей та молоді на позитивні; підтримати, посилити позитивні моральні спонукання, активізувати ї прояви чи загальмувати негативні мотиви, знизити ї силу, утримати учня від прояву негативної мотивації на здоровий спосіб життя.

\section{ЛITEPATУРA}

1. Боднаровська Н. А. Розробка інформаційного проекту «Особистісно-цілісний підхід до формування здорового способу життя» / Н. А. Боднаровська // Біологія : науково-методичнийжурнал. - 2010. - № 14. - C. 7-10.

2. Гендин А. М. Студенты о здоровом образе жизни: желаемая ситуация и реальная действительность / А. М. Гендин, М. И. Сергеев // Теория и практика физической культуры. - 2007. - № 7. - С. 15-19.

3. Єжова О. Ціннісне ставленнядо здоров'я: чинники й умови / О. Єжова / / Краєзнавство. Географія. Туризм. Шкільний світ. - 2009. - № 20. - С. 3-5.
Висновок. Охорона здоров'я людини та виховання здорових дітей були основними проблемами в усі часи. Потребою кожної людини $\epsilon$ здоровий стан організму в поєднанні зі здоровими умовами довкілля. Вирішення проблеми здоров'я людини закладено у самій людині, у знанні й розумінні нею проблем формування, збереження, зміцнення і відновлення власного здоров'я, а також в умінні дотримуватися правил здорового способу життя. Молоді необхідно усвідомити, що наше майбутне - за здоровими людьми, бо лише фрізично і морально здорова людина здатна творити і приносити користь людям.

4. Субота Н. Здоров'я через освіту / Н. Субота // Науковий світ; Атестаційний вісник. - 2007. - № 4. C. 20-21.

5. Шепенюк I. М. Впровадження в суспільну свідомість переваг здорового способу життя, формування національного культу соціально активної, фізично здорової та духовно багатої особистості / І. М. Шепенюк / / Основи здоров'я я фізичнакультура. - 2005. - № 3. - C. 11-12. 